\title{
The use of telecommunications in continuing education in Australia
}

\author{
Bruce Scriven \\ Brisbane College of Advanced Education
}

\begin{abstract}
The article attempts to identify the extent and use of telecommunications in the provision of continuing education courses in Australian Higher Education. Some interesting approaches have been used but future expansion is likely to be restricted by the costs involved.
\end{abstract}

Before examining the specific role and applications of telecommunications in continuing education it is important to look at the context in which continuing education operates.

Continuing education courses in colleges of advanced education are those which do not lead to any recognised award. An institution's program of continuing education activities might include:

(a) Professional development courses. These courses maybe developed in cooperation with industry, commerce or professional organisations. They may be conducted on a part-time basis, by external study or as conferences, seminars or workshops. They may involve the development of instructional materials specifically tailored to meet the needs of industrial and commercial employers or of a professional group. Courses may also be offered for a recognised professional group or employing authority from one or more units provided in accredited advanced education programs.

(b) Personal development courses. These courses are designed to meet the expressed or identified needs of target groups within the general community and although their major emphasis may be on personal development some may also have a vocational bias. 
(c) Visiting students. For a nominal fee institutions might allow interested persons from the community to attend normal, scheduled lectures and tutorials or to receive external studies materials in units offered in accredited courses. Such "visiting" students would not necessarily have fulfilled entry requirements for the particular course in which the unit is offered and would not receive any academic credit for the unit or units undertaken.

The Commonwealth Tertiary Education Commission has formulated some policy guidelines under which institutions are expected to organise their continuing education activities.

These guidelines include the following

- an acknowledgement that continuing education is necessary to accommodate the advance of knowledge and rapid social and technological change.

- a statement that continuing education is an important function of higher education institutions and should be regarded as part of the normal duties of teaching staff.

- advice that costs of continuing education courses should be recouped from fees which should be charged for each course with a view to ensuring that the total costs of each college's program for each year would at least be met.

- advice that institutions should not provide continuing education courses which can be offered more appropriately by others, e.g. voluntary bodies or TAFE institutions.

Hence there exists a situation in which academic staff are expected to use their expertise to provide a wide variety of non-credit programs for the wider community and to charge for the services provided on at least a cost recovery basis. Any surplus income generated is expected to be used for academic purposes within the institution.

Improved technologies make it feasible for institutions to consider using them in the presentation and delivery of continuing education programs and, in particular, to consider whether telecommunications can be used to deliver courses to distant students or to enhance the presentation of existing continuing education courses both on and off campus.

In this context it is important to recognise that telecommunications might be used in a number of different ways. These include:

- a course involving one way communication from teacher to learners might be delivered by radio or television.

- an expert, remote from an institution, might be "brought in" by telephone to contribute to an on campus course. 
- a course may be delivered by television from a studio but make provision for interaction between the presenters and viewers via audio teleconferencing links.

- electronic mail might be used to allow course participants to communicate with each other or the course presenter.

- interaction among course participants might be fostered by using audio teleconferencing.

In most of the above situations it is likely that printed materials would comprise a significant component of the course whereas the telecommunications segment would vary from being an integral and essential component to that of being a desirable, but by no means necessary, complement.

In the last few years there has been an abundance of books, articles, workshops, conferences and seminars devoted to the use of new technologies in education and to the use of telecommunications in distance education. There has been no shortage of trials designed to explore the limitations of the various technologies and determine their applicability to a variety of conditions and circumstances, however very few of these trials appear to have had a lasting impact (at least on higher education) and nowhere does this seem to be more apparent than in the use of telecommunications in continuing education courses at the higher education level.

In collecting material for this paper the author wrote to more than sixty institutions in Australia in an effort to ensure that information about all relevant activities could be included. Unfortunately the responses (50\%) generally could only be described as discouraging. Some institutions either were not involved in continuing education at all and, of those that were, most did not use telecommunications. Two institutions advised that they did not use telecommunications because they did not offer external courses! Perhaps surprisingly some institutions confused external studies award courses with non award continuing education courses and provided details of how telecommunications, in a variety of forms, were being used to present courses to students enrolled in award courses. Most such uses appeared to be of an experimental nature and there is little doubt that those involved will have gained valuable experience. It is also true that many of the techniques, for example the use of radio or of television transmission by satellite, were open ended in the sense that persons other than enrolled students had access to the material being presented. However, although perhaps contributing to the personal and professional development of the community at large, they can hardly be regarded as components of an institution's continuing education activities. 
The fact is that telecommunications are not yet being used to any significant extent in continuing education programs offered in Australia. However a few institutions did begin to explore the possibilities. These all involved the use of television supported by face to face tutorials and seminars and/or audio interaction via telephone lines. The most common programs used were those launched by Learning Network. Three institutions reported that they had contracted with Learning Network to use its programs in 1987 and 1988. The operation of the Learning Network system is basically as follows. Learning Network Pty.Ltd. contracted with the ABC (Australian Broadcasting Corporation) and the SBS (Special Broadcasting Service) to provide time for the transmission of telecourses. The ABC provides both national and individual State services and satellite delivery to outback areas while the SBS service is restricted to the main metropolitan centres. Individual institutions, by paying a licensing fee and a per capita fee, could then enrol a student in a particular course by charging a fee. For this fee students would expect to receive one or more textbooks and other print material to support their understanding of the program and, in some cases, tutorial support or other assistance from the institution with which they enrolled.

Most, if not all, courses used so far were developed in the United States, as were the texts and other learning materials, and the fees that had to be charged by institutions wishing to cover costs were fairly high. Furthermore the transmission times available, for example $7.00-8.00 \mathrm{am}$ on the $A B C$, were not suitable for many potential participants. Courses used included the following:

New Literacy - An Introduction to Computers (30 half-hour programs)

Business of Management (26 half-hour programs)

Business of Hospitality (8 half-hour programs)

Marketing (26 half-hour programs)

At least one institution used audio teleconferencing to support these programs and reported that this proved fairly successful.

It would seem that no Australian produced programs were available to institutions using Learning Network services.

Learning Network courses commenced transmission in March 1987 but have now been discontinued. Given the increasing financial restrictions being placed on institutions, it would be a brave institution that would be prepared to use television as a medium for the transmission of continuing education courses unless financial guarantees were available. In most cases this would require extensive advertising and market surveys, which themselves are costly. 
Hedberg (1988) reported on an evaluation of the first two of the above programs as provided by enrollees at the University of New South Wales and concluded that "...there does appear to be a market for telecourses" and that survey responses suggested "this form of delivery is appropriate and ... it provides some incentive for us to look at the development of courses and materials in this area.". It is doubtful whether this incentive has produced any activity!

The most significant activities in Australia would appear to have been those undertaken by Brisbane College of Advanced Education over a five year period. In 1983 this college, in conjunction with the School Library Association of Queensland, launched the first of a series of continuing education courses involving the use of telecommunications for teachers and teacher librarians throughout the State. The courses became known as TeleSLAQ courses and, as an integral feature, made use of teleconferencing techniques to enable participants to interact with each other and with course presenters.

In 1984 activities were expanded to include live one-way video supported by two-way audio teleconferencing. The video component was broadcast from a studio at Kelvin Grove Campus via a microwave link to the BTQ Channel 7 transmitter and then to regional television stations. Participants in country centres were able to interact with the studio presenters via the standard telephone network. In addition to a live audience in Brisbane, participants attended centres at Darwin, Cairns, Mackay, Maryborough, Mount Isa, Rockhampton and Townsville. The first of these programs involving one-way video with interactive audio was delivered on Sunday 22 July 1985 and had the title Storytelling Across the Curriculum. It would appear to be the first attempt by any higher education institution in Australia to present a continuing education course that made use of both live video and live audio communications.

Further programs were offered in 1985 but, as was to be expected for programs of this kind, costs in terms of staff planning and preparation time, hire of television transmission and reception facilities, could not be recovered from fees. In fact, considerable support was provided by grants from the Commonwealth Department of Education and Youth Affairs and the Queensland Education Department.

With the advent of AUSSAT, Australia's first satellite, and the decision by the Queensland Government to hire one transponder and to set up a network of earth stations, to become known as QNet, the college was presented with a unique opportunity to expand its offerings.

Encouraged by the possibilities, the college succeeded in obtaining a microwave link from its studio on the Kelvin Grove Campus to the main QNet control station at Mineral House in the centre of Brisbane. (From 
here signals are sent to the transmitting dish at Rochedale for uplinking to the satellite.)

Further encouragement was provided by the Queensland Government when it advised that, at least for 1986 and 1987, no charge would be made for the use of the transponder or for the use of earth station facilities in the network. This period was to be used for co-ordinated trials of the system.

The college had already gained considerable experience in the use of audio teleconferencing with external students and for holding meetings (the college has four campuses) and its experience with the TeleSLAQ programs had proved so fruitful that further activity was justified.

Furthermore the college was convinced of the benefits of providing for interaction, the ingredient so often missing from distance education courses, and was not prepared to use this new facility simply to transmit prepackaged programs from its central library.

Hence it embarked on an ambitious program of continuing education courses which built on experience gained in the delivery of the TeleSLAQ series and most of which involved live, and often unrehearsed, video transmissions that allowed for audience/viewer interaction by telephone line direct to presenters on the set. During 1986 and 1987 there were 15 courses delivered using this technique. Some courses involved a series of two hour sessions at weekly intervals whereas others were one-off sessions of two hours. Persons who enrolled in each course and paid the prescribed fee were provided with booklets and other study, or background, materials and although the technology of QNet enabled the college to control the centres able to receive the programs it was not possible, in most cases, to control attendance. Hence, at any one site, there may have been 5 or 6 enrolled students but other non-enrolled students in attendance.

The content of the programs was quite varied and reflected both the specific expertise of academic staff who wished to trial the technique as well as the perceived needs of the community. Details of a few of the programs are provided below.

Reading and Children's Literature - a series of four programs each of 2 hours.

Basic Maths in the Primary School - a series of four programs each of 2 hours.

Once Fired Pottery - one 2 hour program.

AIDS Education - one 1 and a $1 / 2$ hour program.

Getting Started in Teaching - a series of four programs eachof 2 hours.

Implementing the Curriculum for Years 1,2 and 3-a series of four programs each of 2 hours. 
As had been anticipated, some of these courses proved more successful than others both with regard to the number of enrolments received and the quality of the transmitted product. However, even though production costs were tightly controlled, most courses barely managed to generate a profit and certainly would not have done so if it had been necessary to pay for transponder time or for the hire of premises at reception sites.

Brisbane CAE has also used telecommunications to bring outside expertise to on campus students. The college has offered numerous courses for businessmen, educators and others designed to teach audio teleconferencing skills. A segment of each of these courses may involve contacting an "expert" by telephone and allowing the on campus group, using the Hybrid loudspeaking telephone facility, to listen to the "expert" and interact with him or her.

There is some evidence to suggest that the particular uses of telecommunications referred to above as being used by Brisbane CAE have also been trialed by a few other colleges but for the most part they have been restricted to credit programs. Western Australian CAE (WACAE), which has five campuses, reported on quite an extensive use of the Golden West Network (GWN) satellite service to transmit programs but most of these were prerecorded. Live programs that provide for interaction between students and a lecturer via telephone lines have been such that only the target audience, which comprised students enrolled in credit courses, could contact the transmitting studio directly. For a number of years the college also broadcast on Radio 6NR, the public access station operated by the Curtin University of Technology in Perth, and was developing plans to use the twenty-four hour public access state-wide satellite radio channel that has been proposed.

Perhaps the most longstanding use of telecommunications to deliver continuing education programs has been the service delivered by radio stations associated with the University of New South Wales (VL2W) and the University of Adelaide (5W). A report on the first 25 years of the former appears in Australian Journal of Educational Technology, Vol.2, No.2, Summer 1986 and the same issue, which was devoted to the special topic Educational Radio Today, carries reports on the experiences of other institutions. In most cases, however, it seems that institutions were more concerned with general educational broadcasting rather than the specific offering of continuing education.

It must be concluded that telecommunications are not being widely used by institutions of higher education in the provision of continuing education courses. The vast majority of institutions, perhaps wisely, have been prepared to exercise a watching brief and to leave it to the pioneering few to experiment, learn the pitfalls and determine the advantages and the limitations of the technologies available. Continuing education itself 
would appear to be a peripheral activity of the majority of institutions and as it has to be provided on a cost recovery basis by staff prepared to work additional hours it is perhaps not surprising that attempts to try anything new by way of course delivery and presentation have been minimal. Experience to date would seem to suggest that unless seed monies or subsidies are made available there is unlikely to be a significant change in this situation in the foreseeable future.

\section{Bibliography}

Australian Journal of Educational Technology, 2(2), Summer 1986.

http:/ / www.ascilite.org.au/ajet/ ajet2/ajet2.html

Department of Education (Qld) (1987). Education and the Satellite. Issues of February, June, July.

Dept. of Industry Development (Qld) (1985-87). Q-Net Update. No.1, July 1985; No.2, July 1986; No.3, July 1987.

Hedberg, J. G. (1988). Marketing courses to professionals. Educational Media International, 25(4), 235-241.

Kenworthy, B. (1989). Educational Broadcasting - Just for Kids. Australian Journal of Educational Technology, 5(1), 47-55. http:/ / www.ascilite.org.au/ajet/ajet5/kenworthy.html

Lazer, E. A., Elton, M. C. J., Johnson, J. W. et al. (1983). The Teleconferencing Handbook: A Guide to Cost Effective Communication. White Plains, NY: Knowledge Industry.

Stahmer, A. (1987). Communications Technology and Distance Learning in Canada. Ottawa: Department of Communications.

Teleguide: A Handbook for Video-Teleconference Planners. (1981). Washington DC: Public Service Satellite Consortium.

Author: Bruce Scriven, B.Sc., M.Ed (Syd), Dip.Ed (NE), M. Ed Admin (Qld), MACE, ASIA. is Head, Extension Services at Brisbane College of Advanced Education, President of the Australian and South Pacific External Studies Association and a member of the Executive of the International Council for Distance Education. His address is Brisbane College of Advanced Education, Locked Bag No 2, Kelvin Grove, Qld 4059.

Please cite as: Scriven, B. (1989). The use of telecommunications in continuing education in Australia. Australian Journal of Educational Technology, 5(2), 105-112.

http: / / www.ascilite.org.au/ajet/ajet5/ scriven.html 